\title{
Antioxidant activities, total phenolic and flavonoid contents of honey collected from different botanical origins
}

\author{
Deniz AKER ${ }^{a}$, Cevat NISBET ${ }^{b, \bowtie}$ \\ Ondokuz Mayıs University, Faculty of Veterinary Medicine, Department of Biochemistry, Samsun, Turkey. \\ aORCID:0000- 0003-3959-6713; ' $\mathrm{ORCID:}$ 0000-0002-7042-4605 \\ ${ }^{\bowtie}$ Corresponding author: cnisbet@omu.edu.tr \\ Received date: 07.02.2019- Accepted date: 21.12.2019
}

\begin{abstract}
In this study, it is aimed to determine the presence of antioxidant capacity, total phenolic and flavonoid contents in six different types (multiflora, pine, chestnut, sunflower, acacia, citrus) and eventually 65 samples of honey from different parts of Turkey. Pollen analysis of all honey samples in the laboratory was carried out to determine the purity (> 65-70\%) of the plant source. Total phenolic content determined in honey samples was found the highest value in pine honey $166.46 \pm 5.80$ (mgGAE / $100 \mathrm{~g}$ honey) while the lowest value was found in flower honey with $(106.04 \pm 9.55)$. The level of flavonoid contents of the groups was lowest on the flower and citrus honey $(1.3 \pm 0.2$ and $1.6 \pm 0.1)$ and the highest value were on chestnut and pine $(2.7 \pm 0.4$ and $2.8 \pm 0.2)$ were detected. Comparing the radical scavenger activity in honey groups, the activity of chestnut honey was the highest (100.54 \pm 22.72$)$. The results of this study show that the phytochemical structure and biological activity of honey are completely different from each other depending on the plant source. On the other hand, it is possible to say that the antioxidant, phenolic, and flavonoid values are high, which is a good indicator of the quality and naturalness of honey.
\end{abstract}

Keywords: Antioxidant, flavonoid, honey, honey bee, phenolic acid.

\section{Farklı botanik kaynaklardan elde edilen balların antioksidan aktiviteleri, toplam fenolikleri ve flavonoid içerikleri}

Özet: Bu çalışmada, Türkiye'nin çeşitli bölgelerinde üretilmiş 6 farklı çeşit (yayla, çam, kestane, ayçiçeği, akasya, narenciye) toplam 65 bal numunesinde toplam fenolik asit, flavonoid düzeyi ve total antioksidan aktivitesi incelenmiştir. Laboratuvarda tüm bal numunelerinin polen analizi yapılarak bitki kaynağının saflık derecesi (>\%65-70) tespit edilmiştir. Bal örneklerinde belirlenen total fenolik içeriği 166,46 $\pm 5,80(\mathrm{mgGAE} / 100 \mathrm{~g}$ bal) ile en yüksek değer çam balına ait iken, en az 106,04 $\pm 9,55$ ile çiçek balında bulunmuştur. Gruplar arası flavonoid içeriği en düşük düzey çiçek ve narenciye balında sırasıyla $(1,3 \pm 0,2$ ve $1,6 \pm 0,1)$, en yüksek değer ise kestane ve çam balında $(2,7 \pm 0,4$ ve $2,8 \pm 0.2)$ tespit edilmiştir. Bal gruplarında yapılan radikal süpürücü aktivitesinin karşılaştırılmasında ise kestane balın aktivitesinin en yüksek olduğu $(100,54 \pm 22,72)$ ortaya konulmuştur. Çalışmanın sonuçları, balın fitokimyasal yapısı ve biyolojik aktivitesinin bitki kaynağına bağlı olarak birbirinden tamamen farklı olduğunu göstermektedir. Diğer taraftan bu değerlerin yüksek olması balın kalitesinin ve doğallığının iyi bir göstergesi olacağını söylemek mümkündür.

Anahtar sözcükler: Antioksidan, bal, balarısı, fenolik asit, flavonoid.

\section{Introduction}

For centuries, bees and bee products have been used for therapeutical purposes. Today, they maintain their actuality in the field of supportive therapy and show a fast development under the name of apitherapy. Honey, which is one of the apitherapy products and one of the oldest nutritional sources of mankind, is a sweet product which bees collect from flower nectars or from secretions of some insects living on plants and store in honeycombs by exposing them to enzymatic change $(3,6,22)$. The formation and composition of honey produced naturally differ significantly according to regions and sources of the plant (23). The composition of plant nectar differs according to the geography the plant is grown in, soil fertility, rainfall, light, altitude and a great number of other environmental factors $(14,24)$. In other words, the quality and biochemical characteristics of honey differ according to the source of nectar $(8,13,22)$. Studies conducted show that the antioxidant activity of natural foods is higher than food products with synthetic structure (18). For this reason, daily intake of antioxidant food is important and required for free radicals which form as a metabolism product in the organism. In addition to being a food product and source of energy, honey is also important for human health as a natural antioxidant source due to various phytochemicals it includes $(3,12,17)$. 
Antioxidant compositions of honey are enzymatic (glucose oxidase, catalase, peroxidase) or non-enzymatic (phenolic acids, flavonoids, ascorbic acid, tocopherol, carotenoids) (18, 19). Phenolic acids contribute significantly to the antioxidant activity of honey $(1,17)$. Flavonoids have a significant antioxidant and antiinflammatory function by providing free-radical scavenging, inhibiting cyclooxygenase and lipooxygenase enzymes, chelating transition metals such as iron and copper, protecting $\alpha$-tocopherol at LDL and providing oxidizable ascorbic acid regeneration (16). The rates of these compositions in honey differ significantly depending on the source flora honey is collected from and the structure of the geographical areas $(8,12,23)$. For this reason, every honey has a different apitherapic value. The present study researches the biological activities of honey obtained from different regions and plant sources of Turkey.

\section{Materials and Methods}

Sampling: The study was conducted with a total of 65 honey samples from different regions of Turkey (11 sample meadow honey from the provinces of Erzurum and Sivas, 11 sample pine honey from Muğla, 11 sample chestnut honey from Sinop, 11 sample Acacia honey from Trabzon, 10 sample from citrus tree honey from Antalya and 11 sample sunflower honey from Samsun). Pollen analyses of all samples were made in the laboratory and purity degree of plant sources was found $(>65-70 \%)$.
Biochemical analysis: Calculation of the total antioxidant effect in the samples was made according to the free radical scavenging effects of the prepared extracts on DPPH (1,1-diphenyl-2-picrylhydrazyl) in honey by using an indirect method. As a result of DPPH radical scavenging activity, IC50 values were assessed as $\mathrm{mg} / \mathrm{ml}$. The measurement was made according to Meda and Dimins method modified at $520 \mathrm{~nm}$ with a spectrophotometer $(9,21)$. AA $[\%]=($ Abs cont-Abs sample)/ Abs cont.X100. Total phenolic concentration level was read at $750 \mathrm{~nm}$ in spectrophotometer with FolinCiocalteau method and the total phenol amount was calculated as equivalent to $\mathrm{mg}$ gallic acid in 100 gram extract (4, 9). The Dowd method was used in total flavonoid analysis. In this method, honey solutions prepared based on quercetin (mgQE/100gr) concentration in $\mathrm{mg}$ in a kilogram of honey were read at $415 \mathrm{~nm}$ with a spectrophotometer $(9,21)$.

Statistical analysis: The data obtained from the study were evaluated with the variance analysis (ANOVA) technique in factorial order and the differences between the means were determined by Duncan multiple comparison test. Statistical evaluations were made using the SPSS statistical program (26).

\section{Results}

Average values of total phenolic, flavonoid levels and antioxidant activity found in honey samples of groups are given in (Table 1, Figure1).

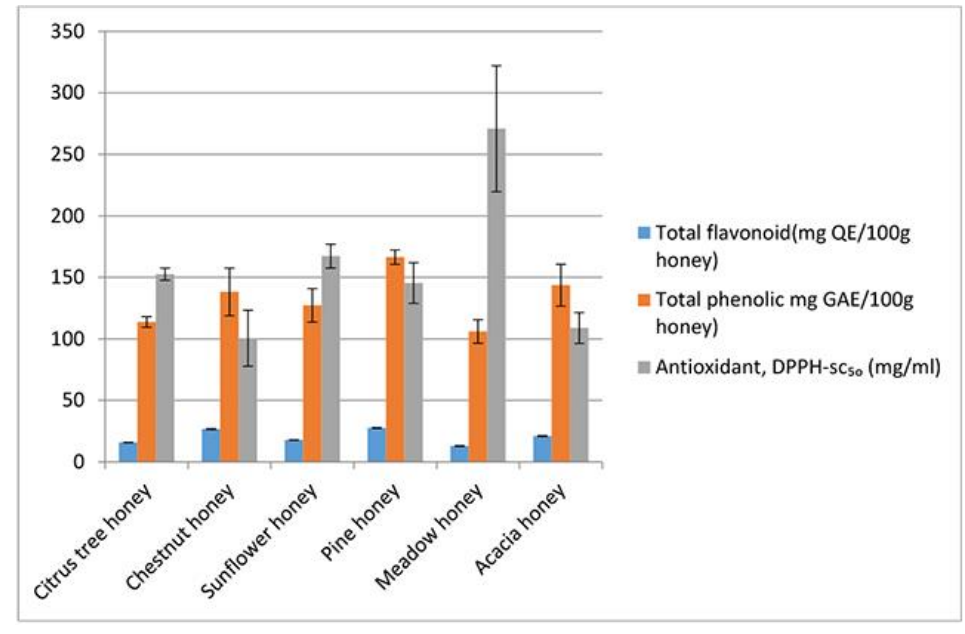

Figure 1. Means of total phenolic, flavonoid and antioxidant analysis results in honey samples

Table 1. Means and standard errors of total phenolic (mg GAE/100 g), flavonoid QE/100 g) and antioxidant (mg/ml) in honeys samples produced from different botanical origins.

\begin{tabular}{lcccccc}
\hline Samples & $\begin{array}{c}\text { Total } \\
\text { flavonoid }\end{array}$ & (Min-Max) & Total phenolic & (Min-Max) & $\begin{array}{c}\text { Antioxidant, } \\
\text { DPPH-sc }_{\mathbf{5}_{\mathbf{0}}}\end{array}$ & (Min-Max) \\
\hline Citrus tree honey & $1.6 \pm 0.1$ & $1.2-1.9$ & $113.77 \pm 4.27$ & $100.21-120.62$ & $152.65 \pm 4.96$ & $140.40-163.91$ \\
Chestnut honey & $2.7 \pm 0.4$ & $1.4-4.0$ & $138.27 \pm 19.31$ & $97.64-206.22$ & $100.54 \pm 22.72$ & $41.05-165.03$ \\
Sunflower honey & $1.8 \pm 0.5$ & $1.7-2.0$ & $127.27 \pm 13.54$ & $88.03-127.33$ & $167.33 \pm 9.69$ & $135.40-198.81$ \\
Pine honey & $2.8 \pm 0.2$ & $2.1-3.6$ & $166.46 \pm 5.80$ & $149.37-186.11$ & $145.48 \pm 16.49$ & $93.61-206.38$ \\
Meadow honey & $1.3 \pm 0.2$ & $0.5-1.9$ & $106.04 \pm 9.55$ & $68.85-130.94$ & $270.86 \pm 51.22$ & $136.17-506.38$ \\
Acacia honey & $2.1 \pm 0.4$ & $1.3-3.5$ & $143.71 \pm 16.99$ & $71.16-183.06$ & $108.91 \pm 54.00$ & $69.34-142.55$ \\
\hline
\end{tabular}


The highest total phenolic composition was found in pine honey with $166.46 \pm 5.80$ (mgGAE/100g honey), while the lowest value was found in flower honey with $106.04 \pm 9.55$. While the intergroup flavonoid composition lowest value was found in flower and citrus honey $(1.30 \pm 0.2$ and $1.6 \pm 0.1)$, the highest value was found in chestnut and pine honey $(2.7 \pm 0.4$ and $2.8 \pm 0.2)$. Radical scavenging activity comparison of honey groups showed that chestnut honey had the highest activity $(100.54 \pm 22.72)$ As a result of the analysis of variance, there was a significant difference between the honey samples $(\mathrm{P}<0.01)$.

\section{Discussion and Conclusion}

Phenolic acids and flavonoids, which are components of honey, are important due to their antimicrobial, antioxidant, anticancer and antioxidative effects and their being associated with human and animal health and on the other hand due to being a criterion for honey's being refined $(1,5,6,22)$. The concentration of these compounds which significantly affects honey's therapeutic activity differs according to plant flora which constitutes the sources of honey (11).

In the present study, it was found that total phenolic composition differed between 106 - $166 \mathrm{mgGAE} / 100 \mathrm{~g}$ in all honey samples. While the lowest concentration was found in flower honey, the highest concentration was found in pine honey (Figure1). Similarities and differences are seen between our study results and the results of the studies previously conducted. While total phenolic acid concentration was reported as 32.59-114.75 mgGAE/100 gr and an average of $74.38 \pm 20.54$ in South African honey samples (21), phenolic acid concentration was reported as 36.26-102.80 mgGAE/100g and an average of $65.31 \pm 19.50$ in a study conducted with Nigeria honey (5). Vit et al., (28) reported in their study that phenolic matter amount differed between 38.15 and $182.10 \mathrm{mgGAE} / 100 \mathrm{~g}$ in Venezuela honey. Total phenolic amount in Yemeni honey obtained from different regions and different plants differed between 56.32 and 246.21 $\mathrm{mg} / 100 \mathrm{~g}(1)$. In a study conducted on the honey in the Indian Bengal region, it was reported that gallic acid rates per $100 \mathrm{~g}$ honey differed between $9.9 \pm 0.6$ and $44.7 \pm 2$ $\mathrm{mg}$ (7). In a study conducted with different honey from Slovenia, the total phenolic composition was found as $241.4 \mathrm{mg} / \mathrm{kg}$ in fir tree honey, as $233.9 \mathrm{mg} / \mathrm{kg}$ in chestnut honey and as $44.8 \mathrm{mg} / \mathrm{kg}$ in acacia honey (4). In studies conducted on acacia honey, total phenolic compositions differ significantly among countries. While Iranian acacia honey total phenolic content was found as $22.9-65.5 \mathrm{mg}$ gallic acid/g (15), it was found as $627 \pm 44.03$ in Germany acacia honey (2). In a study conducted on the honey of
Black Sea flora, average phenolic content was found as $0.224 \mathrm{mg}$ as gallic acid equivalent for $1 \mathrm{~g}$ honey sample (11).

In the study, while the lowest average total flavonoid (mgQE/100g honey) value of honey was found in flower honey with an average of $1.3 \pm 0.2$ the highest value was found in chestnut honey with an average of $2.7 \pm 0.4$. In a study conducted on Indian honey, quercetin $(\mathrm{mg} / 100 \mathrm{~g})$ amount was found to be between $5.12 \pm 0.23$ and $19.4 \pm$ 1.38 (Das et al., 2013). In Brazilian multiflora and citrus honey, quercetin $(\mathrm{mg} / 100 \mathrm{~g})$ composition was reported as $1.96 \pm 1.53$ and $0.17 \pm 0.15$, respectively (20). In a study conducted on Malesian honey, flavonoid average value was reported as $5.42 \pm 0.62$ (19). In China unifloral honey, flavonoid average value was reported to differ between 9.41 and 102.1 (10). In a study conducted in South Africa, the total flavonoid composition average was reported as $2.57 \pm 2.09$ in 27 honey samples (21). In a study conducted on pine honey in our country, total flavonoid level was found as $22.80 \pm 2.45$ on average in $\mathrm{QE} / \mathrm{kg}$ honey equivalent (25). In the present study, this value was found as $2.8 \pm 0.2$ in the same honey type.

In the study, total antioxidant activity was found as $100.54 \pm 22.72$ in chestnut honey and as $270.86 \pm 51.22$ in multiflora flower honey. When studies conducted in many countries were examined in terms of their similarities and differences of these values, it was found that radical scavenger DPPH average IC50 $=23.92 \pm 1.12 \mathrm{mg} / \mathrm{mL}$ in Indian honey (7), the same value was found as $10.0 \pm 1.8$ and $10.7 \pm 2.2$, respectively in Slovenian chestnut and flower honey (4); average antioxidant activity was found as $31.96 \pm 18.07$ in chestnut honey in Brazilian multifloral honey and as $15.22 \pm 10.75$ in citrus honey (20), while antioxidant activity was reported as 35-122 in China unifloral honey (10). Ertürk et al. (11) found IC50 values as between 29.388 and $458.450 \mathrm{mg} / \mathrm{mL}$ as a result of the DPPH radical scavenging activity test in Black Sea flora honey in our country.

Some studies show a correlation between the phenolic compound level and antioxidant activity in some types of honey; however, since flavonoids have hydroxyl, they are oxidized very quickly. For this reason, despite structural similarities, the difference between antioxidant activities depends on hydroxylation and methylation degree (1). In our study, no correlation was found between groups. It is possible to say that this is because in addition to flavonoid and phenolic acid, the presence of Vitamin $\mathrm{E}$ and $\mathrm{C}$ and carotenoids may have influenced total antioxidant activity (27).

Consequently, our observations that phytochemical structure and biological activity of honey differ completely depending on the origins of the plant. 


\section{Acknowledgments}

The authors thank Dr. Serhat Arslan for editing the content of this manuscript related to the statistical analysis. This article is produced from master's thesis of the first author.

\section{Financial Support}

This work was supported by Ondokuz Mayis University, Scientific Research Projects Unit (BAP) under project number (PYO.VET.1904.13.006).

\section{Conflict of Interest}

The authors declared that there is no conflict of interest.

\section{References}

1. Al-Mamary M, Al-Meeri A, Al-Habori M (2002): Antioxidant activities and total phenolics of different types of honey. Nutr Res, 22, 1041-47.

2. Alzahrani H, Boukraa L, Bellik Y, et al (2012): Evaluation of the antioxidant activity of three varieties of honey from different botanical and geographical origins. Global J Health Sci, 4, 191-196.

3. Atrott J, Henle T (2009): Methylglyoxal in Manuka honey - correlation with antibacterial properties. Czech J Food Sci, 27, 163-165.

4. Bertoncelj J, Dobersek U, Jamnik M, et al (2007): Evaluation of the phenolic content, antioxidant activity and colour of Slovenian honey. Food Chem, 105, 822-28.

5. Buba F, Gidado A, Shugaba A (2013): Analysis of biochemical composition of honey samples from North-East Nigeria. Biochem Anal Biochem, 2, 139-40.

6. Ching H, Hou YC, Hsiu SL, et al (2002): Influnce of honey on the gastrointestinal metabolism and disposition of glycyrhizm and glycyrhetic acid in rabbits. Biol Pharm Bull, 25, 87-91.

7. Das A, Mukherjee A, Dhar P (2013): Characterization of antioxidants and antioxidative properties of various unifloral honeys procured from West Bengal, India. IOSRJESTFT, 7, 56-638.

8. Demirezen D, Aksoy A (2010): Determination of heavy metals in bee honey using by inductively coupled plasma optical emission spectrometry (ICP-OES). GU J Sci, 18, 569-575.

9. Dimins F, Kuka P, Augspole I (2010): Characterisation of honey antioxidative properties. International Conference of Food Innova, 28-29- Oct. Latvia.

10. Dong R, Zheng Y, Xu B (2013): Phenolic profiles and antioxidant capacities of Chinese unifloral honeys from different botanical and geographical sources. Food Bioprocess Technol, 6, 762-770.

11. Ertürk Ö, Şahin H, Kolaylı S, et al (2014): Antioxidant and antimicrobial activity of East Black Sea. Turk J Biochem, 39, 99-106.
12. Gheldof N, Wang XH, Engeseth NJ (2002): Identification and quantification of antioxidant components of honeys from various floral sources. J Agric Food Chem, 50, 58705877.

13. Giorgi A, Madeo M, Baumgartner J, et al (2011): The Relationships between phenolic content, pollen diversity, physicochemical information and radical scavenging activity in honey. Molecules, 16, 336-342.

14. Güler A, Bakan A, Nisbet C, et al (2007): Determination of important biochemical proreties of honey to discriminate pure and adulterated honey with sucrose (Saccharum officinarum L.) syrup. Food Chem, 105, 1119-1125.

15. Javanmardia J, Stushnoff C, Locke E, et al (2003): Antioxidant activity and total phenolic content of Iranian Ocimum accessions. Food Chem, 83, 547-550.

16. Kahraman A, Serters M, kokenT (2002): Flavonoids, Kocatepe Med J, 3, 1-8.

17. Kesic A, Mazalovic M, Crnkic A, et al (2009): The Influence of L-Ascorbic Acid Content on Total Antioxidant Activity of Bee-Honey. Eur J Sci Res, 32, 95-101.

18. Kesic A, Crnkic A, Hodžic Z, et al (2012): Influence of Polyphenol Content on total Antioxidant Activity of Honey from Different Botanical and Geographical Origin. Eur J Sci Res, 89, 500-511.

19. Khalil MI, Sulaiman SA, Boukraa L (2010): Antioxidant properties of honey and its role in preventing health disorder. Open Nutraceuticals J, 3, 6-16.

20. Lianda RLP, Sant'ana LD, Echevarria A, et al (2012): Antioxidant activity and phenolic composition of Brazilian honeys and their extracts. J Braz Chem Soc, 23, 618-627.

21. Meda A, Lamien CE, Romito M, et al (2005): Determination of the total phenolic, flavonoid and proline contents in Burkina Fasan honey, as well at their radical scavenging activity. Food Chem, 91, 571-577.

22. Nisbet C, Kazak F, Yuksel A (2018): Determination of quality criteria that allow differentiation between honey adulterated with sugar and pure honey. B1ol Trace Elem Res, 186, 288-293.

23. Nisbet C, Guler A, Bıyı S (2019): Effects of different environmental conditions on the cognitive function of honeybee (Apis mellifera L.) and mineral content of honey. Ankara Üniv Vet Fak Derg, 66, 95-101.

24. Oddo LP, Bogdanov S (2004): Determination of honey botanical origin: problems and issues. Apidologie, 35, 2-3.

25. Ozkok A, Darcy B, Sorkun K (2010): Total total phenolic acid and total flavonoid content of Turkish pine honeydew honey. JAAS, 2, 65-71.

26. SPSS. Statistical package for the social sciences User's guide. SPSS Inc. 2004. Chicago IL 60606-6412, USA.

27. Vinson JA, Hontz BA (1995): Phenol antioxidant index: comparative antioxidant effectiveness of red and whitewines. J Agric Food Chem, 43, 401-403.

28. Vit P, Rodríguez-Malaver A, et al. (2009): Expanded parameters to assess the quality of honey from Venezuelan bees (Apis mellifera). JAAS, 1, 72-81. 